\title{
PENGARUH MENDENGARKAN MURATTAL AL QURAN TERHADAP PENINGKATAN KEMAMPUAN KONSENTRASI
}

\author{
Very Julianto, Rizki Putri Dzulqaidah, Siti Nurina Salsabila \\ UIN Sunan Gunung Djati Bandung, J1. A.H. Nasution 105 \\ e-mail: very_psi07@yahoo.com
}

\begin{abstract}
The study aimed to determine the effectiveness of listening murattal Al Qur'an in increasing concentration capability. Subjects in this study were the girls students of Universitas Islam Negeri Sunan Gunung Djati Bandung, 18-20 years old, with GPA is above 3,00. The measurement of this study is using Digit Span test. The data were analyzed by using a statistical parametric $T$ test. The mean score of concentration gained by the experimental group subjects before treatment was10,4, and after treatment was 11,2. While the mean score of the control group subjects before treatment was 11, and after treatment was 11,4. The result can be interpreted that there was mean differences between the experimental group and the control group before and after treatment. It means that listening murattal is effective in increasing the capability of concentration.
\end{abstract}

Keywords: concentration, murattal, Al Quran

\begin{abstract}
Abstrak
Penelitian ini bertujuan untuk melihat pengaruh mendengarkan murattal Al Qur'an terhadap peningkatan kemampuan konsentrasi. Subyek penelitian adalah mahasiswa perempuan Universitas Islam Negeri Sunan Gunung Djati Bandung, yang berusia 18-20 tahun dan memiliki IPK diatas 3,00. Pengukuran menggunakan tes Digit Span. Data dianalisa dengan menggunakan statistik parametrik T test. Nilai rata-rata skor konsentrasi subyek dalam kelompok eksperimen sebelum perlakuan adalah 10,4, sedangkan setelah perlakuan adalah11,2. Sedangkan perolehan skor rata-rata subyek pada kelompok kontrol sebelum perlakuan adalah 11 dan setelah perlakuan 11,4. Nilai rata-rata tersebut menunjukkan bahwa terdapat perbedaan nilai rata-rata antara kelompok eksperimen dan kelompok kontrol pada kondisi sebelum dan setelah perlakuan. Hal ini menunjukkan bahwa mendengarkan murattal Al Qur'an berpengaruh pada peningkatan kemampuan konsentrasi.
\end{abstract}

Kata kunci: konsentrasi, murattal, Al Quran

\section{PENDAHULUAN}

Konsentrasi merupakan bagian penting dalam kehidupan manusia. Konsentrasi berkaitan dengan usaha individu dalam memfokuskan perhatiannya terhadap suatu objek, sehingga individu dapat memahami dan mengerti objek yang diperhatikannya. Konsentrasi dapat mengurangi terjadinya divided attention (perhatian yang terpecah). Divided attention terjadi karena pikiran dalam memahami masalah saling berkompetisi dan memecah perhatian (Crick \& Koch, 2003). Perhatian individu akan mudah beralih dari suatu objek ke objek lain apabila individu tersebut tidak dapat berkonsentrasi. Hal ini menyebabkan individu kurang mampu memahami suatu objek secara utuh. Hal ini dikarenakan adanya proses Long Term Potential (LTP) dan Long Term Depression (LTD).

LTP dan LTD adalah suatu proses asosiasi neuron dalam otak. Neuronneuron yang ada dalam korteks manusia akan saling berkoalisi dan juga berkompetisi. Neuron-neuron yang saling berkoalisi akan saling membantu dan menguatkan proses sinapsis antar maeraka. Sedangkan neuro-neuron yang berkompetisi akan saling melemahkan. Proses ini akan menghasilkan koalisi neuron sebagai pemenang. Koalisi neuron yang menang akan memberikan pengalaman belajar (Crick, F. \& Koch, C, 2003).

Konsentrasi yang baik juga menjadi salah satu faktor yang dapat membawa 
keberhasilan dalam prose pembelajaran. Konsentrasi menjadi kunci dalam proses memori baik saat menyimpan informasi atau saat mengeluarkan informasi (Nuryana, 2010). Individu yang mengalami gangguan dalam konsentrasinya menjadi kesulitan dalam memfokuskas konsentrasinya. Hal ini membuat individu tersebut membutuhkan waktu lebih lama dalam menangkap informasi yang disampaikan (Aini, 2012).

Konsentrasi merupakan keadaan pikiran atau asosiasi terkondisi yang diaktifkan oleh sensasi di dalam tubuh. Seseorang memerlukan kondisi yang rileks dan suasana yang menyenangkan untuk mengaktifkan sensasi tersebut. Apabila kondisi tegang atau stres dapat membuat aktivitas berpikirnya tidak maksimal (Dennison, 2008). Kecemasan dan ketegangan baik ketegangan otot maupun ketegangan pikiran dapat mempengaruhi tingkah laku. Hal ini menyebabkan individu menjadi stres dan tidak nyaman dalam memproses informasi yang ada (Aini, 2012).

Pada saat stres terjadi peningkatan kadar kortisol yang akan mengganggu aktivitas dari hippocampus yang berakibat menurunkan kemampuan konsentrasi (McEwen, 1998). Konsentrasi tertinggi apa bila seseorang tersebut dalam kondisi gelombang theta $(3 \mathrm{~Hz}-7 \mathrm{~Hz})$. Otak menciptakn LTP dalam bentuk gelombang theta (Kalat, 2007).Gelombang theta sering terekam pada korteks parietal dan juga korteks temporan pada anak-anak. Gelombang theta banyak dihasilkan pada saat melakukan berbagai kegiatan keagamaan (Julianto, 2011; Schiffer, 2003; Guyton \& Hall, 2000; Garrett, 2003).

Kesulitan dalam berkonsentrai banyak disebabkan oleh ketegangan otot dan juga ketegangan pikiran. Goldfried dan Davidson (dalam Aini, 2012) menyatakan bahwa relaksasi adalah salah satu teknik dalam terapi perilaku untuk mengurangi ketegangan dan kecemasan. Individu yang mengalami ketegangan dan kecemasan akan mengakibatkan aktifnya sistem saraf simpatetis. Relaksasi dapat menekan rasa tegang dan cemas dengan cara resiprok, sehingga timbul counterconditioning dan penghilangan (Prawitasari, 1988). Relaksasi sendiri adalah kembalinya satu otot pada keadaan istirahat setelah mengalami kontraksi atau peregangan atau suatu keadaan tegangan rendah tanpa emosi yang kuat (Chaplin, 1968). Perkembangan terbaru menunjukkan bahwa relaksasi bisa dikombinasi dengan dzikir. Metode ini dikenal dengan relaksasi religius (Abdurrochman dkk, 2008).

Dr. Al Qadhi (Syakir, 2014), melalui penelitiannya yang panjang dan serius di Klinik Besar Florida Amerika Serikat, berhasil membuktikan hanya dengan mendengarkan bacaan ayat-ayat Al-Qur'an, baik mereka yang bisa berbahasa Arab maupun bukan, dapat merasakan perubahan psikologis yang sangat besar. Penurunan depresi, kesedihan, ktenangan jiwa, menangkal berbagai macam penyakit merupakan pengaruh umum yang dirasakan orang-orang yang menjadi objek penelitiannya. Penelitiannya ditunjang dengan bantuan peralatan elektronik terbaru untuk mendeteksi tekanan darah, detak jantung, ketahanan otot, dan ketahanan kulit terhadap aliran listrik. Dari hasil uji cobaannya ia berkesimpulan, bacaan Al-Qur'an berpengaruh besar hingga 97\% dapat melahirkan ketenangan jiwa dan penyembuhan penyakit.

Penelitian Dr. Al Qadhi ini diperkuat pula oleh penelitian lainnya yang dilakukan oleh dokter yang berbeda. Dalam laporan yang disampaikan dalam Konferensi Kodekteran Islam Amerika Utara pada tahun 1984 disebutkan, Al-Qur'an terbukti mampu mendatangkan ketenangan sampai $97 \%$ bagi mereka yang mendengarkannya. Kesimpulan hasil uji coba tersebut diperkuat lagi oleh penelitian Muhammad Salim yang dipublikasikan di Boston. Objek penelitiannya terhadap 5 orang sukarelawan yang terdiri dari 3 pria dan 2 wanita. Kelima orang tersebut sama sekali tidak mengerti bahasa Arab dan mereka pun tidak diberi tahu bahwa yang akan diperdengarkannya adalah Al-Qur'an. 
Penelitian yang dilakukan se-banyak 210 kali ini terbagi dua sesi, yakni membacakan Al-Qur'an dengan tartil dan membacakan bahasa Arab yang bukan dari Al-Qur'an. Kesimpulannya, responden mendapatkan ketenangan sampai $65 \%$ ketika mendengarkan bacaan Al-Qur'an dan mendapatkan ketenangan hanya 35\% ketika mendengarkan bahasa Arab yang bukan dari Al-Qur'an(Syakir, 2014). Hal ini sesuai dengan firman Allah, "Dan apabila dibacakan Al Qur'an, maka dengarkanlah baik-baik, dan perhatikanlah dengan tenang agar kamu mendapat rahmat. (QS. 7:204)".

Dengan menurunnya kecemasan dan ketegangan yang dialami seseorang maka diharapkan dapat meningkatkan konsentrasi. Penelitian ini bertujuan untuk mengetahui seberapa besar pengaruh mendengarkan murattal terhadap pe-ningkatan kemampuan konsentrasi. Hipotesisnya adalah terdapat perbedaan kemampuan konsentrasi antara individu sebelum diperdengarkan murattal dan setelah diperdengarkan murattal.

\section{METODE PENELITIAN}

\section{Variabel Penelitian}

Variabel independen adalah Murattal Al Quran. Sementara, variabel dependennya adalah kemampuan konsentrasi.

\section{Definisi Operasional}

Murattal Al Quran

Murattal adalah pembacaan ayat AlQuran dengan mengguanakan tajwid yang benar dan berirama. Murattal yang dijadikan eksperimen adalah ayat-ayat AlQuran yang dipilih sendiri oleh subjek, yang mana akan diperdengarkan selama tes berlangsung.

Kemampuan Konsentrasi

Konsentrasi adalah kemampuan individu memusatkan perhatiannya terhadap sesuatu objek sehingga dapat mengingat sesuatu dengan baik.

\section{Subjek Penelitian}

Peneliti mengambil 10 subjek penelitian dengan kriteria sebagai berikut:

1. Jenis kelamin perempuan

2. Usia 18-20 tahun

3. $\quad \mathrm{IPK} \geq 3,00$

\section{Instrumen Penelitian}

Penelitian ini menggunakan alat ukur, yaitu tes digit span forward dan backward dari subtes Wechsler Intelegensi Scale. Digit span forward berjumlah 9 soal dan digit span backward berjumlah 8 soal. Penelitian-penelitian sebelumnya menunjukkan tes digit spanforward dan backward valid dan reliabel (Nanik, 2009; Huwae, 2008).

\section{Desain Penelitian}

Desain penelitian ini menggunakan jenis penelitian eksperimental-kuasi (quasi-experimental design) Pretest-Posttest Control Group Design. Rancangan Pretest-Posttest Control Group Design digunakan untuk menguji efek suatu perlakuan terhadap variabel dependen. Pengujian dilakukan dengan cara membandingkan hasil pretes dan posttest variabel dependen pada kelompok eksperimen (Shaughnessy, 2006). Pretest menginformasikan kemampuan awal (initial position) para subjek sebelum dilakukan penelitian. Menurut Robinson (Seniati, 2011), konstansi terjadi karena skor variabel terikat adalah skor hasil posttest dikurangkan dengan hasil pretest setiap subjek.Jadi skor yang diperoleh adalah peningkatan atau penurunan variabel terikat akibat dilakukannya penelitian.Apabila skor post-test lebih besar dari pre-test, maka dapat disimpulkan bahwa mendengarkan murattal dapat meningkatkan konsentrasi belajar

\section{Prosedur Penelitian}

10 subjek penelitian dibagi menjadi dua kelompok, yaitu kelompok eksperimen dan kelompok kontrol.Subjek penelitian dari masing-masing kelompok diberikan pretestberupa tes digit span forward dan 
digit span backward. Pretest pada masingmasing kelompok diberikan secara terpisah. Tes digit span forward diberikan hingga maksimal 9 kali percobaan. Angkaangka dikatakan dengan jarak 1 detik, dan subjek penelitian diminta mengucapkan kembali deretan angka yang telah dibacakan sebelumnya. Kemudian tes digit span backward diberikan hingga maksimal 8 kali percobaan. Angka-angka dikatakan dengan jarak 1 detik, dan responden diminta mengucapkan kembali secara terbalik dari urutan dari angka paling belakang hingga angka paling depan pada deretan angka yang telah dibacakan sebelumnya.

Pada kelompok eksperimen diberikan perlakuan berupa mendengarkan murottal Al Quran selama 30 menit. Setelah diberikan perlakuan, subjek pada kelompok eksperimen diberikan posttest berupa mengerjakan kembali tes digit span forward dan digit span backwardseperti yang dilakukan saat pretest.

Pada kelompok kontrol tidak diberikan perlakuan. Subjek penelitian diberikan posttestdengan mengerjakan kembali tes digit span forward dan digit span backwardseperti yang dilakukan saat pretest.

\section{Analisis}

Data dikumpulkan dan dianalisis secara kuantitatif menggunakan uji statistika $t$ test.T test digunakan untuk menguji signifikansi perbedaan pada data berskala ukur interval, yaitu perbedaan antara mean $\mu$ populasi dengan nilai $\bar{x}$ yang diperoleh dari sampel (Siegel, 1992; Sudjana, 2005).

\section{HASIL}

Tabel 1. Hasil Penelitian Kelompok Eksperimen

\begin{tabular}{ccc}
\hline NO & Pretest & Posttest \\
\hline $\mathbf{1}$ & 10 & 15 \\
$\mathbf{2}$ & 10 & 10 \\
$\mathbf{3}$ & 12 & 9 \\
$\mathbf{4}$ & 10 & 10 \\
$\mathbf{5}$ & 10 & 12 \\
\hline
\end{tabular}

Tabel 2.Hasil Penelitian Kelompok Kontrol

\begin{tabular}{ccc}
\hline NO & SEBELUM & SESUDAH \\
\hline $\mathbf{1}$ & 14 & 12 \\
$\mathbf{2}$ & 8 & 10 \\
$\mathbf{3}$ & 8 & 9 \\
$\mathbf{4}$ & 13 & 14 \\
$\mathbf{5}$ & 12 & 12 \\
\hline
\end{tabular}

Poin pada tabel hasil penelitian kelompok eksperimen dan kelompok kontrol diatas didapatkan dari hasil penjumlahan antara skor digit span forward dandigit spanbackward dari subtes Wechsler Intelegensi Scale.Skor tersebut ialah jumlah angka terakhir yang mampu dilafalkan dengan benar oleh subjek penelitian.

Analisis Deskriptif

\begin{tabular}{lcccc}
\hline \multicolumn{1}{c}{ Nilai } & \multicolumn{2}{c}{ Pretest } & \multicolumn{2}{c}{ Posttest } \\
& KE & KK & KE & KK \\
\multicolumn{1}{c}{ Rata-rata } & 10,4 & 11 & 11,2 & 11,4 \\
\hline Varians & 0,8 & 8 & 5,7 & 3,8 \\
Simpangan & 0,89 & 2,8 & 2,3 & 1,9 \\
baku & & & & \\
Jumlah Siswa & 5 & 5 & 5 & 5 \\
Nilai & 12 & 14 & 15 & 14 \\
$\begin{array}{l}\text { Tertinggi } \\
\text { Nilai } \\
\text { Terendah }\end{array}$ & 10 & 8 & 9 & 9 \\
\hline
\end{tabular}

Tabel 3.Nilai Pretest Dan Posttest Antara Kelompok Eksperimen Dan Kelompok Kontrol

Keterangan:

$\mathrm{KE}=$ Kelompok Eksperimen

$\mathrm{KK}=$ Kelompok Kontrol 


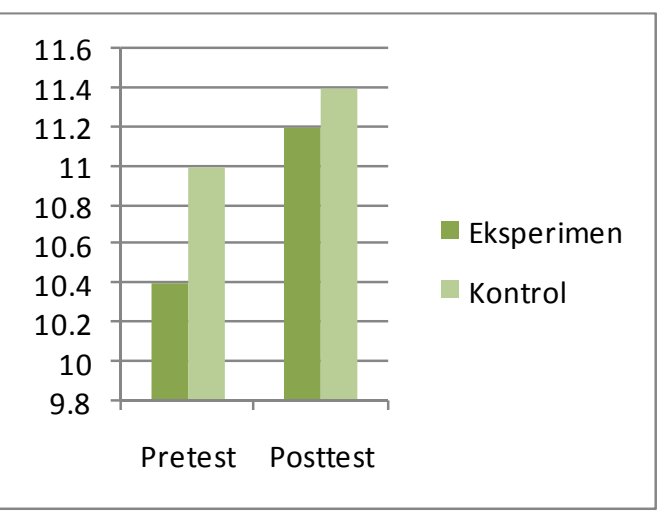

Gambar 1. Grafik Hasil

Dari tabel tersebut diketahui bahwa rata-rata untuk pretest kelompok eksperimen adalah 10,4, sedangkan posttest kelompok eksperimen adalah 11,2 artinya rata-rata pretest kelompok eksperimen lebih kecil dari rata-rata posttest kelompok eksperimen, hal ini membuktikan bahwa setelah diberikan perlakuan mendengarkan murattal, konsentrasi akan meningkat. Simpangan baku pretest kelompok eksperimen adalah 0,89; sedangkan simpangan baku posttest kelompok eksperimen adalah 2,3. Dan variansi untuk pretest kelompok eksperimen adalah 0,8 , sedangkan variansi untuk posttest kelompok eksperimen adalah 5,7 .

Rata-rata pretest kelompok kontrol adalah 11, sedangkan rata-rata posttest kelompok kontrol adalah 11,4, artinya tingkat konsentrasi meningkat setelah dilakukan pengujiankembali. Simpangan baku pretest kelompok kontrol adalah 2,8; sedangkan simpangan baku posttest kelompok kontrol adalah 1,9. Dan variansi pretest kelompok kontrol adalah 8, sedangkan variansi posttest kelompok kontrol adalah 3,8.

Keterangan:

- Rata-rata adalah hasil penjumlahan nilai-nilai anggota sebuah kelompok $\left(\sum X n\right)$ dibagi jumlah anggota kelompok tersebut.

- Varians adalah ukuran-ukuran keragaman data statistic yang paling sering digunakan.
- Simpangan Baku adalah akar kuadrat dari varians

\section{Uji normalitas}

Uji normalitas bertujuan untuk mengetahui apakah data berdistribusi normal atau tidak. Untuk menguji normalitas digunakan uji Chi-Kuadrat.

Tabel 4. Nilai Chi Kuadrat

\begin{tabular}{lcccc}
\multicolumn{1}{c}{ Variabel } & Db & $\chi^{2}{ }_{\text {hitung }}$ & $\chi_{\text {tabel }}^{2}$ & Ket. \\
\hline $\begin{array}{l}\text { Kemampuan } \\
\text { awal }\end{array}$ & 1 & 1.66 & 3.84 & Normal \\
(pretest) & & & &
\end{tabular}

(pretest)

$\begin{array}{lllll}\text { Kemampuan } & 1 & 0.4 & 3.84 & \text { Normal }\end{array}$

akhir

(posttest)

Untuk mengetahui apakah data tersebut berdistribusi normal, $\chi_{\text {hit }}^{2}<\chi_{\text {tabel }}^{2}$. Dari data tersebut diperoleh bahwa:

a. Pretest: $\chi_{\text {hit }}^{2}=1.66<\chi_{0,05(1)}^{2}=3.84$; artinya data berdistribusi normal.

b. Posttest: $\chi_{\text {hit }}^{2}=0.4<\chi_{0,05(1)}^{2}=3.84$; artinya data berdistribusi normal

\section{Uji Homogenitas}

Uji homogenitas bertujuan untuk mengetahui varians antar kelompok.Untuk menguji homogenitas varians digunakan uji-F.

Tabel 5. Nilai $F$

\begin{tabular}{lccc}
\hline \multicolumn{1}{c}{ Variabel } & $\mathbf{f}_{\text {hitung }}$ & $\mathbf{f}_{\mathbf{0}, \mathbf{0 5}(\mathbf{1}, \mathbf{8})}$ & Keterangan \\
\hline $\begin{array}{l}\text { Kemampuan } \\
\text { awal } \\
\text { (pretest) }\end{array}$ & 1.6 & 5.32 & Homogen \\
\hline $\begin{array}{l}\text { Kemampuan } \\
\text { akhir } \\
\text { (posttest) }\end{array}$ & 0.33 & 5.32 & Homogen \\
\hline
\end{tabular}

Untuk mengetahui apakah data tersebut homogen, $\mathrm{F}_{\text {hit }}<\mathrm{F}_{\text {tabel }}$. Dari data tersebut diperoleh bahwa:

a. Pretest: $\mathrm{F}_{\text {hit }}=1.66<\mathrm{F}_{\mathrm{tab}}=5.32$; artinya data tersebut homogen.

b. Posttest: $F_{\text {hit }}=0.33<F_{\text {tab }}=3.84$; artinya data tersebut homogen 


\section{Pengujian Hipotesis}

Sebelum dilakukan uji hipotesis, terlebih dahulu uji rata-rata kesamaan dua kelompok, yaitu:

a. Uji kesamaan rata-rata pretest kelompok kontrol dan kelompok eksperimen dengan menggunakan statistik uji-t. Hipotesis statistik: $\mathrm{H}_{0}$ : $\mu_{\mathrm{ek} 1}=\mu_{\mathrm{kt} 1}$ dan $\mathrm{H}_{1}: \mu_{\mathrm{ek} 1} \neq \mu_{\mathrm{kt} 1}$. Untuk penerimaan hipotesis nol, menggunakan kriteria terima $\mathrm{H}_{0} \mathrm{jika}-\mathrm{t}_{1-1 / 2 \alpha ; \mathrm{dk}}<\mathrm{t}<\mathrm{t}_{1-1 / 2}$ $\alpha$; dk, dimana $\mathrm{dk}=\left(\mathrm{n}_{1}+\mathrm{n}_{2}-2\right)$ dan $\alpha=$ 0,05 .

b. Uji kesamaan rata-rata posttest kelompok kontrol dan kelompok eksperimen dengan menggunakan statistik uji-t.

Hipotesis statistik: $\mathrm{H}_{0}: \mu_{\mathrm{ek} 2}=\mu_{\mathrm{k} t 2}$ dan $\mathrm{H}_{1}$ : $\mu_{\mathrm{ek} 2} \neq \mu_{\mathrm{kt} 2}$.Untuk penerimaan hipotesis nol, menggunakan kriteria terima $\mathrm{H}_{0}$ jika $-\mathrm{t}_{1-1 / 2}$ $\alpha ; \mathrm{dk}<\mathrm{t}<\mathrm{t}_{1-1 / 2} \alpha$; dk, dimana $\mathrm{dk}=\left(\mathrm{n}_{1}+\mathrm{n}_{2}-2\right)$ dan $\alpha=0,05$.

Tabel 6. Hasil T-test dan kesimpulan hipotesis

\begin{tabular}{lccc}
\hline $\begin{array}{l}\text { Variabel } \\
\text { Pretest }\end{array}$ & $\begin{array}{c}\mathbf{t}_{\text {hitung }} \\
-0,1\end{array}$ & $\begin{array}{c}\mathbf{t}_{\text {tabel }} \\
1,8\end{array}$ & $\begin{array}{c}\text { Keterangan } \\
t_{\text {hitung }}<\mathrm{t}_{\text {tabel }} \\
\text { Ho ditolak }\end{array}$ \\
\hline Posttest & $-0,15$ & 1,8 & $\begin{array}{c}t_{\text {hitung }}<\mathrm{t}_{\text {tabel }} \\
\text { Ho ditolak }\end{array}$ \\
\hline
\end{tabular}

Berdasarkan data diatas, diperoleh hasil bahwa mendengarkan murattal memberikan pengaruh yang signifikan terhadap peningkatan kemampuan konsentrasi.

\section{DISKUSI}

Setelah dilakukannya pengujian dengan menggunakan instrument penelitian digit span, kelompok eksperimen menunjukan adanya perbedaan yang signifikan antara sebelum dan sesudah diberikannya treatment. Sedangkan pada kelompok kontrol tidak terdapat perbedaan antara sebelum dan sesudah.

\section{Eksperimen}

Pengujian yang dilakukan sebelum diberikannya treatment hanya 1 orang yang memenuhi kriteria lolos dari subjek penelitian 5 orang, sedangkan pengujian yang dilakukan setelah diberikan treatment subjek penelitian yang lolos ada 2 orang dari 5 orang. Dilihat dari grafik tersebut jumlah subjek penelitian yang lolos bertambah, artinya mendengarkan murattal mempengaruhi peningkatan kemampuan konsentrasi.

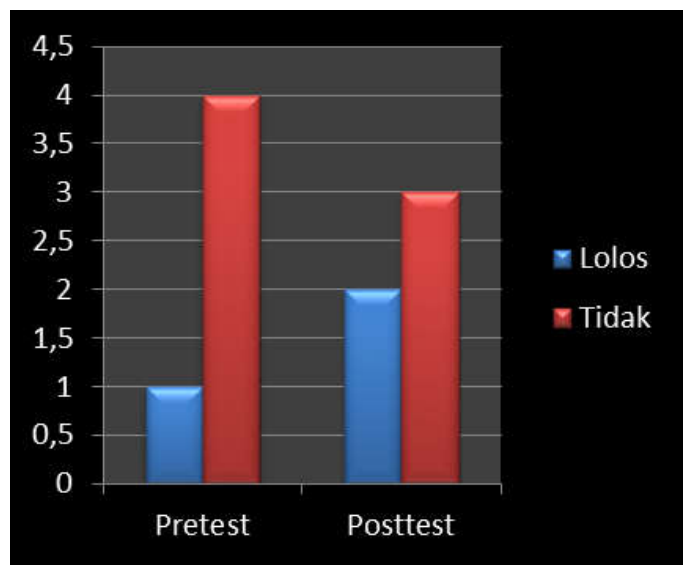

Gambar 2. Grafik Hasil Kelompok Eksperimen

\section{Kontrol}

Pengujian yang dilakukan tidak menggunakan treatment, pada pretest subjek penelitian yang lolos ada 3 orang dari 5, dan pada posttest subjek penelitian yang lolos juga ada 3 orang dari 5 orang. Dilihat dari grafik tersebut jumlah subjek penelitian yang lolos tetap, artinya penelitian yang dilakukan sebelum dan sesudah tanpa menggunakan treatment tidak ada perbedaannya

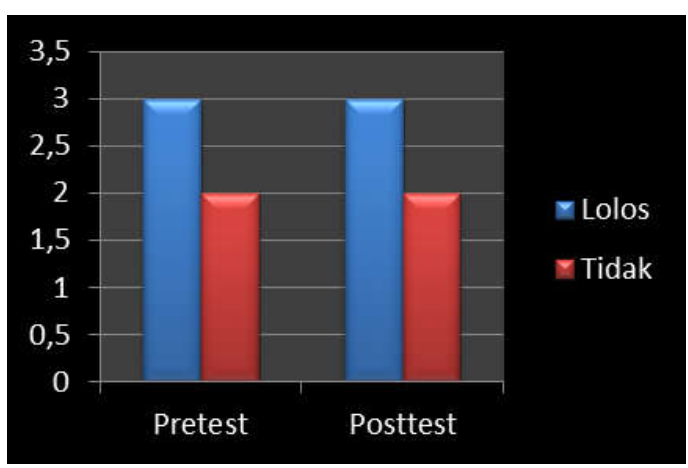

Gambar 3. Grafik Hasil Kelompok Kontrol 
Hal ini menunjukkan bahwa mendengarkan murattal memengaruhi kemampuan konsentrasi. Ada pula faktor lain yang memengaruhi konsentrasi, yaitu kecemasan. Kecemasan menurut Asmadi (2008) dalam Putri (2014), merupakan gejolak emosi seseorang yang berhubungan dengan sesuatu di luar dirinya dan mekanisme diri yang digunakan dalam mengatasi permasalahan, terlihat jelas bahwa kecemasan mempunyai dampak terhadap kehidupan seseorang, baik dampak positif maupun negatif.

Kecemasan merupakan suatu perasaan subjektif mengenai ketegangan yang menyebabkan kegelisahan sebagai reaksi dari ketidakmampuan mengatasi masalah atau tidak memiliki rasa aman. Perasaan tidak menentu tersebut nantinya akan menimbulkan perubahan fisiologis dan psikologis (Rochman, 2010).

Perubahan fisiologis tersebut diantaranya adalah; jari tangan dingin, detak jantung makin cepat, berkeringat dingin, kepala, kepala pusing, nafsu makan berkurang, tidur tidak nyenyak, dan dada sesak. Sedangkan perubahan psikologis yang terjadi adalah; ketakutan merasa akan ditimpa bahaya, tidak dapat memusatkan perhatian, tidak tenteram, ingin lari dari kenyataan (Rumini, 2004).

Menurut Nevid (2005) ada tiga jenis gejala kecemasan diantaranya yaitu:

a. Gejala fisik dari kecemasan yaitu kegelisahan, anggota tubuh bergetar, banyak berkeringat, sulit bernafas, jantung berdetak kencang, merasa lemas, panas dingin, mudah marah atau tersinggung.

b. Gejala behavioral dari kecemasan yaitu berperilaku menghindar, terguncang, melekat dan dependen.

c. Gejala kognitif dari kecemasan yaitu khawatir tentang sesuatu, perasaan terganggu akan ketakutan terhadap sesuatu yang terjadi di masa depan, keyakinan bahwa sesuatu yang menakutkan akan segera terjadi, ketakutan akan ketidakmampuan untuk menyelesaikan masalah, pikiran terasa ber- campur aduk atau kebingungan, sulit berkonsentrasi.

Menurut Stuart (2007) manifestasi kecemasan dapat berupa respon-respon sebagai berikut:

a. Respon fisiologis

1) Respon kardiovaskuler seperti palpitasi, jantung berdebar, tekanan darah tinggi, rasa mau pingsan, tekanan darah menurun, denyt nadi menurun.

2) Respon pernafasan seperti nafas, nafas pendek, tekanan pada dada, nafas dangkal, pembengkakan tenggorokan, sensai tercekik, ternagh-engah.

3) Respon neuromuskuler seperti reflex meningkat, reaksi kejutan, mata berkedip-kedip, insomnia, tremor, rigiditas, gelisah, wajah tegang, kelemahan umum, kaki goyah, gerakan yang janggal.

4) Respon gastrointestinal seperti kehilangan nafsu makan, menolak makan, rasa tidak nyaman pada abdomen, mual, rasa terbakar pada jantung, diare.

5) Respon traktus urinarius seperti tidak dapat menahan kencing, sering berkemih.

6) Respon kulit antara lain wajah kemerahan, berkeringat setempat, gatal, rasa panas dan dingin pada kulit, wajah pucat, berkeringat seluruh tubuh.

b. Respon perilaku seperti: gelisah, ketegangan fisik, tremor, bicara cepat kurang koordinasi, cenderung mendapat cedera, menarik diri dari hubungan interpersonal, melarikan diri dari masalah.

c. Respon kognitif meliputi perhatian terganggu, konsentrasi buruk, salah dalam memberikan penilaian.

d. Respon afektif meliputi hambatan berpikir, bidang persepsi menurun, kreativitas dan produktivitas menurun, bingung, sangat waspada, kesadaran meningkat, kehilangan objektivitas, takut kehilangan control, takut pada 
gambaran visual, takut cidera, mudah terganggu, tidak sabar, gelisah, tegang, ketakutan, tremor, gugup, gelisah.

Menurut Oken (2004) musik dapat memiliki efek terapeutik pada pikiran dan tubuh manusia. Efek suara dapat memengaruhi keseluruhan fisiologis tubuh pada basis aktivasi korteks sensori dengan aktivitas sekunder lebih dalam pada neokorteks dan beruntun ke dalam sistem limbik, hipotalamus, dan sistem saraf otonom. Saraf kranial kedelapan dan kesepuluh membawa impuls suara melalui telinga.Dari sini, saraf vagus, yang membantu regulasi kecepatan denyut jantung, respirasi dan bicara, membawa impuls sensorik motorik ke tenggorokan, laring, jantung, dan diafragma.Para ahli terapi suara menyatakan saraf vagus dan sistem limbik (bagian otak yang bertanggung jawan untuk emosi) merupakan penghubung antara telinga, otak, dan sistem saraf otonom yang menjelaskan bagaimana suara bekerja dalam menyembuhkan gangguan fisik dan emosional (Oken, 2004).

Salah satu terapi musik yakni perangsangan auditori. Menurut Oken (2004), perangsangan auditori adalah memberikan perangsangan pada pendengaran dengan menggunakan suara. Suara bergerak di udara dengan kecepatan 340 $\mathrm{m} /$ detik, terdiri dari getaran-getaran dari seumbernya sampai mencapai telinga, kemudian melalui telinga ini ia menyebar ke seluruh tubuh. Sel yang terpengaruhi oleh vibrasi suar, berespon dengan mengubah vibrasinya sendiri, yang berarti bahwa kerja mekanik dari sel ini dapat meningkat dan menjadi lebih kuat.Sel-sel otak bervibrasi serta mengirimkan gelombang magnet dan elektromagnetik yang mewakili aktivitas otak.Sel-sel otak dipengaruhi oleh segala vibrasi apapun jenisnya dan darimanapun sumbernya.

Suara manusia merupakan instrument penyembuhan yang sangat ampuh karena suara manusia memberi energi. Suara member keseimbangan kepada otak secara sempurna dalam waktu sekejap dan mampu menciptakan fokus (Rodan, 2001). Dari program pengobatan Integratif Universitas Arizona, pakar kesehatan alternative Dr. Andrew Weil menyebut music sebagai karunia getaran penyembuhan. Rumah Sakit Universitas di Cleveland menyatakan bahwa risetnya hanya membutuhkan sesi terapi musik saja karena merupakan indikator penting dari fungsi kekebalan, di sentral ini terapi music diterapkan untuk mengurangi kecemasan dan depresi juga mengurangi rasa nyeri karena meningkatnya protein dalam tubuh serta mengurangi infeksi (Salampessy, 2004).

Alternatif lain selain terapi musik menurut Remolda (2009) dalam Faradisi (2013) dan Putri (2014) adalah terapi religi. Terapi religi dapat mempercepat penyembuhan, hal ini dibuktikan oleh berbagai ahli seperti yang telah dilakukan oleh Dr. Ahmad Al Qadhi, direktur utama Islamic Medicine Institute for Education and Research di Florida, Amerika Serikat. Dalam konferensi tahunan ke XVII Ikatan Dokter Amerika, wilayah missuori AS, Ahmadi Al-Qadhi melakukan presentasi tentang hsil penelitiannya dengan tema pengaruh Al-Qur'an pada manusia dalam perspektif fisiologi dan psikologi. Hasil penelitian tersebut menunjukkan hasil positif bahwa mendengarkan ayat suci AlQur'an memiliki pengaruh yang signifikan dalam menurunkan ketegangan urat syaraf reflektif dan hasil ini tercatat dan terukur secara kuantitatif dan kualitatif oleh sebuah alat berbasis komputer (Remolda, 2009).

Salah satu terapi religi ini bisa disebut dengan perangsangan auditori murattal.Perangsangan auditori murattal adalah perangsangan pendengaran dengan bacaan ayat-ayat suci Al-Quran yang dikemas dalam bentuk MP3. Ayat-ayat suci Al-Quran mempunyai efek terapeutik bagi yang membaca dan yang mendengarkan (Oken, 2004).

Perangsangan auditori murattal mempunyai efek distraksi yang meningkat- 
kan pembentukan endorphin dalam sistem kontrol desenden dan membuat relakasi otot. Dapat juga digunakan dasar teori Opiate endogenous, dimana reseptor opiate yang berada pada otak dan spinal cord menentukan dimana sistem saraf pusat mengistirahatkan substansi morfin yang dinamakan endorphin dan enkephalin. Opiate endogen ini dapat dirangsang pengeluarannya oleh stimulasi rangsangan. Opiate reseptor ini berada pada ujung saraf sensori perifer (Sri Rezeki, dkk, 2013).

Terapi music dan terapi murattal bekerja pada otak, dimana ketika didorong oleh rangsangan dari luar (terapi musik dan Al-Qur'an), maka otak akan memproduksi zat kimia yang disebut neuropeptide. Molekul ini akan menyangkutkan ke dalam reseptor-reseptor mereka yang ada di dalam tubuh dan akan memberikan umpan balik berupa kenikmatan atau kenyamanan (O'riordan, 2002).

Dari beberapa pendapat di atas, dapat disimpulkan bahwa kecemasan dapat diminimalisir dengan mendengarkan murattal. Dengan menurunnya tingkat kecemasan, maka faktor penghambat konsentrasi akan berkurang sehingga tingkat konsentrasi akan meningkat.

\section{SIMPULAN}

Penelitian kami telah membukti-kan bahwa terdapat hubungan positif antara mendengarkan murattal dengan kemampuan konsentrasi. Berdasarkan hasil penelitian kami, terdapat perbedaan yang cukup signifikan terhadap peningkatan kemampuan konsentrasi antara yang mendengarkan dan tidak mendengarkan murattal. Walaupun masih terdapat faktor lain yang perlu diteliti karena ikut berpengaruh pada kemampuan konsentrasi seseorang.

Hasil penelitian ini memiliki kelebihan dan kelemahan, kelebihan dari penelitian ini adalah hasil dari penelitian mampu membuktikan hipotesis yaitu mendengarkan murattal efektif dalam meningkatkan kemampuan konsentrasi.
Sedangkan kelemahan dari penelitian ini adalah tidak meneliti faktor-faktor lain yang memengaruhi, seperti faktor memori, kondisi ruangan, suhu ruangan, dan banyak hal lainnya.Konsentrasi juga dipengaruhi oleh kondisi fisik atau kondisi biologis seseorang yang masih berpengaruh pada kondisi psikologis orang tersebut.

\section{DAFTAR PUSTAKA}

Abdurrochman, A., Perdana, S. \& Andhika, S. (2008). Muratal Al Quran : Alternatif Terapi Suara Baru. Prosiding Seminar Sains dan Teknologi-II. Lampung.

Aini, S.Q. (2012). Penggunaan Teknik Relaksasi untuk Meningkatkan Konsentasi Belajar Anak Kelas B Taman Kanak-kanak Terate Pandian Sumenep Tahun Pelajaran 20112012.Naskah tidak dipublikasikan, Universitas Negeri Surabaya.

Crick, F. \& Koch, C. (2003).A Framework for Counsciousness.Nature Neuroscience, Vol. 6, 2, p. 119-126.

Dennison, P.E. (2002). Buku Panduan Lengkap Brain Gym. Jakarta: Gramedia.

Faradisi, F. (2012).Efektivitas Terapi Murottal dan Terapi Musik Klasik Terhadap Penurunan Tingkat Kecemasan Pasien Pra Operasi di Pekalongan. Jurnal Ilmiah Kesehatan, Vol V, No. 2

Garrett. (2003). Brain and Behavior. California : Wadsworth \& Thomson.Guyton, A.C. \& Hall, J.E. 2000. Textbook of Medical Physiology. $10^{\text {th }}$ ed. Philadelphia: WB Saunders.

Huwae.F.J, dkk.(2008). Hubungan Kadar Seng ( $\mathrm{Zn})$ dan Memori Jangka Pendek pada Anak Sekolah Dasar. Semarang: Sari Pediatri.

Julianto, V. (2011). Pengaruh Membaca Ayat Al Quran Terhadap Kemampuan Short-Term Memory Dilihat Dari Perubahan Gelombang 
Otak. Jurnal Psikologi Vol38, no 1, Juni 2011:17-29.ISSN: 0215-8884

McEwen, B.S., Flier, J.S. \& Underhill, B.S. (1998). Protective and Damaging Effetcs of Stress Mediators. $N$ Engl J Med. 338(3): 171-179.

Nanik. (2009).Penelusuran Karakteristik Hasil Tes Inteligensi WISC Pada Anak Dengan Gangguan Pemusatan Perhatian dan Hiperaktivitas. Jurnal Psikologi, Vol. 34, No. 1, 18-19.

Nevid, J.S., Rathus, Spencer A., \& Greene, Beverly. 2005. Psikologi Abnormal. 5 th edn, Jilid Pertama. Jakarta: Erlangga.

Nuryana, A\& Purwanto, S.(2010). Efektivitas Brain Gym dalam Meningkatkan Konsentrasi Belajar pada Anak.Naskah tidak dipublikasikan, Fakultas Psikologi, Universitas Muhammadiyah Surakarta

Oken, B. S. (2004). Complementary Therapies in Neurology: An Evidence-Based Approach. USA: The Parthenon Publishing Group.

O'riordan, R.N.L. (2002). Seni Penyembuhan Alami:Rahasia Penyembuhan Melalui Energi Ilahi, diterjemahkan oleh Sulaiman AlKumaiyi dari judul asli The Art of Sufi Healing. Bekasi: Gugus Press.

Putri, D.N. (2014). Pemberian Terapi Murottal Terhadap Penurunan Tingkat Kecemasan Pada Asuhan Keperawatan TN Dengan Pre Operasi Fraktur Collum Femur Sinestra di Ruang Mawar RSUD Dr. Soediran Mangun Sumarso Wonogiri. Surakarta:Naskah Tidak Dipublikasikan, Sekolah Tinggi Ilmu Kesehatan Kusuma Husada.
Rezeki, Sri, dkk. (2013). Tingkat Nyeri Pinggang Kala I Persalinan Melalui Teknik Back-Effluerage dan Counter-Pressure.Jurnal Keperwatan Maternitas.

Rochman, K.L. (2010). Kesehatan Mental. Purwokerto: Fajar Media Press.

Rodan, S. (2001). Terapi Lewat Suara: Bagaimana Menggunakan Kekuatan Penyembuhan Lewat Suara Manusia. Jakarta: Prestasi Pustaka.

Rumini, S\&Sundari, S. (2004). Perkembangan Anak \&Remaja.Jakarta : Rineka Cipta.

Salampessy.(2004). Terapi Musik. Batam: Interaksara.

Schiffer, R.B., Rao, S.M. \& Fogel, B.S. (2003).Neuropsychiatry $2^{\text {nd }} \quad E d$. United State of America : Lippincott Wiliams \& Wikins.

Seniati, dkk.(2011). Psikologi Eksperimen. Jakarta: PT. Index

Shaugnessy, J.J., Zechmeister, E.B., Zechmeister, J.S. (2006). Research methods in psychology. Ne York: McGraw Hill

Siegel, S. (1992). Statistik Non Parametrik. Jakarta: PT. Gramedia Pustaka Utama.

Stuart, Gail. (2007). Buku Saku Keperwatan Jiwa. Jakarta: EGC

Sudjana.(2005). Metoda Statistika. Bandung: PT. Tarsito Bandung.

Syakir, S.,dkk. (2014). Islamic Hypnoparenting: Mendidik Anak Masa Kini Ala Rasulullah. Jakarta: PT. Kawan Pustaka 